\title{
FTIR-ATR SPECTROSCOPIC ANALYSES OF CHANGES IN WOOD PROPERTIES DURING PARTICLE- AND FIBREBOARD PRODUCTION OF HARD- AND SOFTWOOD TREES
}

\author{
Günter Müller, ${ }^{\mathrm{a}}$ Christian Schöpper, ${ }^{\mathrm{b}}$ Hubert Vos, ${ }^{\mathrm{b}}$ Alireza Kharazipour, ${ }^{\mathrm{a}, \mathrm{b}}$ and \\ Andrea Polle ${ }^{a^{*}}$
}

Fourier transform infrared attenuated total reflectance (FTIR-ATR) spectroscopy was combined with multivariate data analysis to investigate the chemical changes in wood during particle- and medium density fibreboard (MDF) production of grand fir (Abies grandis [Douglas ex D. Don] Lindl.) and European beech (Fagus sylvatica L.). The mechanical and technological properties of the novel particle- and fibreboards from beech or grand fir wood were similar to those of conventional panels from pine and spruce. This indicates that these timbers can be used as resources for wood-based panel production. Principal component analysis of FTIR spectra differentiated wood, fibres, particles, MDF, and particleboards of both species in the whole production process. Modifications in the spectra of fibres and particles suggested that cellulose properties of wood were changed during mechanical pulping. Wet chemical analysis confirmed that the furfural content was lower in fibres and higher MDF boards than in wood. Different binders and hydrophobic additives were clearly traceable and discernable in wood composites. Samples from the same production step were clustered together, indicating high homogeneity of the raw materials, and intermediate and final products, respectively. This suggests that FTIR spectroscopy in combination with cluster analysis is a useful tool to assess product quality and can be further developed to control and optimize production processes for innovative wood-based panels.

Keywords: Cluster analysis; European standardisation; FTIR-ATR spectroscopy; Principal component analysis; Urea-formaldehyde resin; Wood-based panels

Contact information: a: Forest Botany and Tree Physiology, Büsgen-Institute, Georg-August-University Göttingen, Büsgenweg 2, 37077 Göttingen, Germany; b: Molecular Wood Biotechnology and Technical Mycology, Büsgen-Institute, Georg-August-University Göttingen, Büsgenweg 2, 37077 Göttingen, Germany; *Corresponding author: apolle@gwdg.de

\section{INTRODUCTION}

\section{Wood Resources}

The demand on wood as a resource for energy is increasing (Wolf 2005; Reich 2008). This leads to a shortage of timber for wood processing industries; in Germany the present stock of timber will be insufficient to meet the needs in the next decades (Behrendt and Rupp 2006). Pöyry Forest Industry Consulting (2006) estimated that European demand for raw material for panel board production will increase from 26 million tons absolutely dry wood in 2005 to 37 million tons in 2015. This will be 
particularly important in Germany, which is the most important panel board producer in Europe (Alteheld 2007).

To ensure long-term supply of wood processing industries, various measures have been suggested, e.g., enlargement of plantations with fast growing tree species in short rotation cycles, utilization of wood from deciduous tree species or fibres from annual plants, mobilization of round wood from privately owned forests, and extension of silviculture with fast growing conifers such as Douglas fir and grand fir (Behrendt et al. 2007; Dohrenbusch and Bolte 2008; Spellmann and Kehr 2008). Douglas fir and grand fir have been introduced into Germany from North America and have a high potential to increase wood production in domestic forests (Röhrig 1981; Nörr 2004). Grand fir seems to be particularly well suited because of its drought tolerance and ecological compatibility (Röhrig 1981). Most present silvicultural programmes in Germany have intensified beech cultivation, because this species is the potentially natural dominant tree in many Central European forests (Ellenberg 1996). However, this species is at risk under the expected climate change, which is predicted to result in significant reductions in precipitation, thus, limiting beech growth habitats (Rennenberg et al. 2004). Furthermore, beech is currently not used in wood-based panel industries because of its high raw density (Wagenführ 2000) and suspected risk of allergies and cancer by hazardous dusts generated during particle and fibre production (Kloeser et al. 2008). Therefore, knowledge of product properties from wood of beech or of introduced tree species is limited.

\section{Need for Innovative Wood Products}

In general, low quality woody parts of harvested trees, small or young trees, and fast growing species are used for wood-based panels (Deppe and Ernst 2000; Ambrozy and Giertlova 2005). Wood shows high variability in its chemical, biological, and physical properties (Wagenführ 2000; Fengel and Wegener 2003). Therefore, large-lot production of massive timber products with unaltered material properties is very difficult to achieve and expensive (Holzwirtschaft Schweiz 2007). To overcome this limitation, wood is chipped and processed to fibres and particles to provide intermediate products for particleboard and medium density fibreboard (MDF) production (Kloeser et al. 2008). Intermediate wood products are glued by adhesives, usually urea-formaldehyde (UF)resin with additives (Youngquist et al. 1997; Kharazipour 2004) under pressure at high temperatures to form wood-based panels. To date, spruce and pine are the main resources for derived timber products (Wagenführ 2000). Since the conventional resources for wood panels are becoming limited, there is a need to introduce novel materials into these processes. Whether the properties of beech and grand fir wood are suitable for use in these production processes and how these processes affect the chemical features of wood of these species is currently unknown.

The aim of this work was to test the usability of wood from beech and grand fir for fibre- and particleboard production and to investigate the chemical changes occurring during wood processing. To this end, we produced MDF and particleboards from grand fir and beech and compared their technological properties with those of reference boards from spruce-pine based industrial processes. To characterize the influence of the production process on the chemical composition of the materials involved, Fourier 
transform infrared-attenuated total reflectance (FTIR-ATR) spectroscopy was applied. FTIR-spectroscopy is a technique to identify molecular units by virtue of the redistribution of excess molecular vibrational energy, i.e., via stretches, wags, scissoring, etc. and has been used to investigate complex polymers in biological samples (Arndt et al. 1999; Kacuráková and Wilson 2001). Attenuated total reflection (ATR), a sampling accessory to FTIR, provides reproducible, qualitative, and quantitative analyses of samples with little or no sample preparation (Bukowski and Monti 2007). The principles and limitations of FTIR-ATR spectroscopy have been reviewed recently (Naumann et al. 2007). FTIR spectroscopy has been used in wood analysis for a long time, because it provides a chemical finger-print of the main organic constituents (Fengel and Wegener 2003). It is suitable for the analysis of bonds between wood, wood components and glues (Fabo 2004). We employed FTIR-ATR in combination with unsupervised multivariate statistical methods to investigate the homogeneity of wood products by cluster analysis and to identify small spectral changes by principal component analysis (PCA).

\section{EXPERIMENTAL}

\section{Wood Materials}

Ten European beech (Fagus sylvatica L.) and ten grand fir (Abies grandis [Douglas ex D. Don] Lindl.) trees, each 56 years old, were harvested in 2006 in the city forest of Schmallenberg (North Rhine-Westphalia, 51¹4'29’' N, 8²3’50' E). The forest stand has west to northwest orientation on a steep slope at an altitude of $600 \mathrm{~m}$. The soil is brown earth with limited nutrient supply. The forest stand was established by planting. At harvest, mean height and breast height diameter of beech were $16 \mathrm{~m}$ and 18 $\mathrm{cm}$, respectively. Grand fir had an average height and breast height diameter of $29 \mathrm{~m}$ and $45 \mathrm{~cm}$, respectively. Wood was used to produce particles and fibres (see below) after cutting two disks from each tree, one at the stem base and one below the crown. From these disks, small blocks (2 per disk) were excised (length: $1 \mathrm{~cm}$, width: $1 \mathrm{~cm}$, height: 2 $\mathrm{cm}$ ), hackled with a chipper to small pieces, and milled to a fine powder (MM 2000, Retsch, Haan, Germany) for 5 minutes at $50 \mathrm{rpm}$. The frequency was raised slowly during the next 5 minutes to $90 \mathrm{rpm}$. The whole milling process took $10 \mathrm{~min}$ for each sample.

\section{Production of Fibres and MDF Boards of Grand Fir and Beech}

Stems of grand fir and beech were debarked manually and cleaved afterwards. Wood pieces were processed to wood chips in a drum chipper (Klöckner Trommelhacker KTH 120 x 400 H2WT, Klöckner Wood Technology GmbH, Hirtscheid, Germany). For pulping, chips were weighed and put into a pressurized laboratory refiner (Laboratory Refiner Type 12, Andritz AG, Graz, Austria). Without any further pre-treatment, chips were pulped for 5 min under thermal and mechanical conditions (thermo mechanical pulp, TMP) of $150^{\circ} \mathrm{C}$ and a pressure of $0.48 \mathrm{MPa}$. Afterwards, the fibres were dried in a gas-heated drying pipe at $125^{\circ} \mathrm{C}$ for $3 \mathrm{~s}$ to achieve the target moisture of $8 \%$.

Ten samples of fibres were taken randomly from different locations of the fibre packages. Fine powder of the dried fibres was prepared for FTIR-ATR analysis as 
described above. To prepare fibres for MDF production, an aqueous solution of a melamine fortified urea-formaldehyde condensation product (MUF-resin) (Kaurit ${ }^{\circledR} 413$ flüssig, BASF AG, Ludwigshafen, Germany, 2008) with a solids content of $68 \%(\mathrm{w} / \mathrm{v})$ containing of $<5 \%(\mathrm{w} / \mathrm{v})$ melamine was utilized. The concentration of the binder was $10 \%$ (solid resin per dry fibre mass (w/w)). A homogeneous, aqueous paraffin-dispersion (HydroWax ${ }^{\circledR} 730$, Sasol, Hamburg, Germany, 2008) with a solids content of $60 \%$ (w/v) and a concentration of $1 \%$ (dry paraffin per dry fibre mass (w/w)) was mixed as the hydrophobic agent with the MUF resin before spraying the glue mixture onto the fibres.

The sprayed fibres were scattered and pressed in a hot-press to fibreboards of a thickness of $10 \mathrm{~mm}$. The pressing process took $3 \mathrm{~min}\left(18 \mathrm{~s} \mathrm{~mm}^{-1}\right)$ at $200^{\circ} \mathrm{C}$ and 2.20 MPa. MDF boards of beech were produced with raw densities of 500,600, 700, and 800 $\mathrm{kg} \mathrm{m}^{-3}$, respectively, and MDF boards of grand fir with densities of 500,600, and $700 \mathrm{~kg}$ $\mathrm{m}^{-3}$, respectively. The board densities resulted from the specific net weight of absolutely dry fibres. For each density two boards were investigated, of which 10 samples were taken.

\section{Particleboard Manufacturing of Grand Fir and Beech}

Particle production

Logs of beech and grand fir were processed to wood chips in a drum chipper (Klöckner Trommelhacker KTH 120 x 400 H2WT, Klöckner Wood Technology GmbH, Hirtscheid, Germany). Wood chips were converted into particles in a knife ring flaker (Condux HS 350, Condux Maschinenbau GmbH. and. Co. KG, Hanau, Germany) with a knife overhang of $0.45 \mathrm{~mm}$ and dried at $100^{\circ} \mathrm{C}$ in a drum drier (ecoDry, SC Technology $\mathrm{GmbH}$, Hendschiken, Switzerland) for $25 \mathrm{~min}$. With a tumbler screening machine (TSM 1200/4, Allgaier Werke GmbH, Uhingen, Germany) the particles were separated into five fractions. Four sieves with a mesh size of $5.0 \mathrm{~mm}, 3.15 \mathrm{~mm}, 1.25 \mathrm{~mm}$, and $0.6 \mathrm{~mm}$ were utilized. Six fractions of particles with different dimensions were received, including particles $>5.0 \mathrm{~mm}$ and $<0.6 \mathrm{~mm}$. As outlined below, different ratios of different particle fractions were utilized. Ten random samples were collected from particle packages consisting of particles of all dimensions. Fine powder of dried particles of beech and grand fir wood was prepared for FTIR-ATR analyses as described above.

\section{Three-layer particleboards of grand fir}

Three layer particleboards were constructed as described elsewhere (Deppe and Ernst 2000). To produce particleboards an aqueous solution of a urea-formaldehyde condensation product (UF-resin) Kaurit ${ }^{\circledR} 350$ flüssig (BASF AG, Ludwigshafen, Germany, 2008) with a solids content of $68 \%(\mathrm{w} / \mathrm{v})$ was utilized. The concentration of binder was $8.5 \%$ (solid resin per dry fibre mass $(\mathrm{w} / \mathrm{w})$ ) for the intermediate layer and $10 \%$ (solid resin per dry particle mass (w/w)) for the surface layer. A homogeneous, aqueous paraffin dispersion (HydroWax ${ }^{\circledR}$ 138, Sasol, Hamburg, Germany, 2008) with a solids content of $60 \%(\mathrm{w} / \mathrm{v})$ was used as a hydrophobic agent with final concentrations of $2 \%$ (dry paraffin per dry particle mass (w/w)) for the intermediate layer and 1\% (dry paraffin per dry particle mass (w/w)) for the surface layer. Ammonium sulphate (AppliChem GmbH, Darmstadt, Germany) with a solids content of 33\% (w/v) was used as hardener at concentrations of $2 \%$ (dry hardener per solid resin $(\mathrm{w} / \mathrm{w})$ ) for the 
intermediate layer and 1\% (dry hardener per solid resin (w/w)) for the surface layer. Paraffin and hardener were admixed to the UF-resin before spraying the glue mix onto the particles and pressing the boards. The surface layer of the three-layer particleboard consisted of $50 \%$ particles of $1.25 \mathrm{~mm}$ and $50 \%$ particles of $0.6 \mathrm{~mm}$. The intermediate layer was composed of $20 \%$ particles $>5.0 \mathrm{~mm}, 60 \%$ particles of $3.15-5 \mathrm{~mm}$ and $20 \%$ particles of $1.25-3.15 \mathrm{~mm}$. Grand fir particles with $10 \%$ moisture for the surface and 8.5\% for the intermediate layer were sprayed with the binder (see above) and paraffin, scattered, and pressed in a hot-press to three-layer particleboards with a thickness of 20 $\mathrm{mm}$. The weight ratios (\%) of the surface layers to the intermediate layer were 20:60:20 of absolutely dry particle mass. The boards were pressed for $4 \mathrm{~min}\left(12 \mathrm{~s} \mathrm{~mm}^{-1}\right)$ at $200^{\circ} \mathrm{C}$ and 2.20 MPa. Board densities of grand fir of 500,600, and $700 \mathrm{~kg} \mathrm{~m}^{-3}$, respectively, were produced. The board density resulted from the specific net weight of absolutely dry particles. Two boards were investigated per density, of which 10 samples were taken.

\section{Monolayer particleboards of beech}

For particleboards from beech UF-resin (Kaurit ${ }^{\circledR}$ Leim 350 flüssig) (BASF AG, Ludwigshafen, Germany, 2008)) with a solids content of $68 \%$ (w/v) was utilized. The concentration of binder for monolayer boards was $8.5 \%$ (solid resin per dry fibre mass (w/w)). Paraffin (HydroWax ${ }^{\circledR}$ 138, Sasol, Hamburg, Germany) with a solids content of $60 \%(\mathrm{w} / \mathrm{v})$ was used with a concentration of $2 \%$ (dry paraffin per dry particle mass (w/w)). Ammonium sulphate (AppliChem GmbH, Darmstadt, Germany) with solids content of $33 \%(\mathrm{w} / \mathrm{v})$ was used as hardener at a concentration of $2 \%$ (dry hardener per solid resin (w/w)). Paraffin and hardener were admixed to UF resin before spraying the glue mix onto the particles and pressing the boards. Monolayer particleboard consisted of particles of all dimensions. Beech particles were sprayed with composite binder of UF resin Kaurit ${ }^{\circledR}$ Leim 350 flüssig, ammonium sulphate, and HydroWax ${ }^{\circledR}$ 138, scattered, and pressed in a hot-press to monolayer particleboards of $20 \mathrm{~mm}$ thickness. The pressing process took $4 \mathrm{~min}\left(12 \mathrm{~s} \mathrm{~mm}^{-1}\right)$ at $200^{\circ} \mathrm{C}$ and $2.20 \mathrm{MPa}$. The particleboards of beech had densities of 600 and $700 \mathrm{~kg} \mathrm{~m}^{-3}$. Ten samples were taken of 2 boards of each density.

\section{Production of Reference Boards MDF boards}

Industrial fibres (Steico AG, Feldkirchen, Germany) of Pinus sylvestris and Pinus radiata (mixing ratio 1:1) were used. The fibres were produced of wood chips, pulped at temperatures of $160-180^{\circ} \mathrm{C}$ and pressure of 0.8-1.2 MPa. They were decomposed in a defibrator (L 36, Sunds Defibrator Industries, Solna, Sweden) at a constant pressure of 1.1 MPa. The production process was the same as described above for MDF boards of beech and grand fir with one difference: mUF Kaurit ${ }^{\circledR}$ Leim 465 flüssig was used instead of mUF Kaurit ${ }^{\circledR}$ Leim 413 flüssig (BASF AG, Ludwigshafen, Germany).

\section{Three-layer particleboards}

Industrial particles (Pfleiderer Holzwerkstoffe GmbH \& Co. KG, Gütersloh, Germany), composed of saw dust (45\%), solid wood (30\%), and wood chips (25\%) were used. The saw dust originated from the sawmill industry, the chips were produced of pulp- and recycling wood, which contained spruce and pine as major fractions and small 
amounts of beech. The same production protocol was applied as that described above for three-layer particleboards of grand fir.

\section{Determination of Furfural}

Samples of milled wood, fibres, and MDF boards were boiled in hydrogen bromide by a method of Jayme and Büttel (1968) with small modifications described by Schöpper (2006). Furfural was determined spectroscopically in the distillate of boiled samples and used to calculate pentosan contents. The pentosan contents of grand fir and beech were multiplied by factors of 2 and 1.33, respectively, to obtain the hemicellulose contents (Augustin and Puls 1982; Lohmann 1998).

\section{FTIR-ATR Spectroscopy and Multivariate Data Analysis}

FTIR-ATR spectra were recorded in the wavenumber range from 4500-600 $\mathrm{cm}^{-1}$ with an Equinox 55 spectrometer (Bruker Optics, Ettlingen, Germany), including a deuterium triglycinesulfate detector and an attached ATR unit (DuraSamplIR, SensIR Europe, Warrington, England). A resolution of $4 \mathrm{~cm}^{-1}$ and 32 scans per sample were used. The samples of solid wood, fibres, and particles were powdered. Specimens of massive MDF (length: $5 \mathrm{~cm}$, width: $1 \mathrm{~cm}$, height: $1 \mathrm{~cm}$ ) and particleboards (length: $5 \mathrm{~cm}$, width: 1 $\mathrm{cm}$, height: $2 \mathrm{~cm}$ ) were investigated. 12 (wood) or 10 (fibres, particles, board) replicates were analysed and averaged. For analysis of three-layer-particleboards, measurements were performed at 5 positions per board by pressing the ATR crystal at the cut edge within the area of the surface layer and at 5 further positions by placing the ATR crystal on the middle layer. For analysis of other board types, the ATR crystal was pressed at 10 different positions at the cut edge of the board. If not indicated otherwise, 10 individual samples were analysed per experimental variable, thus, yielding 100 to 120 spectra. Because of the high spectral homogeneity of liquid UF-resin and HydroWax ${ }^{\circledR}, 3$ FTIRATR measurements were performed on each sample.

The heterogeneity of the recorded FTIR-ATR spectra was investigated by cluster analysis using standard software (OPUS 6.5, Bruker Optics, Ettlingen, Germany). According to their spectral heterogeneity, spectra were classified into clusters or classes in dendrograms. The first derivative of vector normalized (9 smoothing points) spectra across the whole range of wavenumbers (4500-600 $\mathrm{cm}^{-1}$ ) was used to create a distance matrix. For calculating the spectral distances Ward's Algorithm was applied.

Principal component analysis (PCA) is a method for data reduction that gives information about the major components of the spectra that are dominant factors determining differences among samples. A typical spectrum contains several hundred data points (or variates); but these variates will normally be correlated with each other to some extent. PCA removes the redundancy of having many points varying in a correlated way by transforming the original data into a set of new, uncorrelated variates, termed the principal component (PC) scores. PCA identifies directions (principal components) along which the variance of the data is maximal. The effect of this process is to concentrate the sources of variability in the data into the first few PCs. Plots of the so called PC scores (projection on to PC axes) against one another reveal clustering or structure in the data set and generate information about the major components responsible for variability in certain regions of the spectrum. For PCA of our data set, the first derivative of vector 
normalized spectra (9 smoothing points) of the whole wavenumber range (4500-600 $\mathrm{cm}^{-1}$ ) and factorisation were used. Three PCAs were used to generate PC plots with the OPUS 6.5 software (Bruker Optics, Ettlingen, Germany).

\section{Mechanical and Technological Properties of MDF and Particleboards}

Technological properties were determined according to EU standards. Internal bond strength (EN 319), bending strength (EN 310), and surface soundness for particleboards only (EN 311) were measured with a universal testing machine (T1FR010TH.A50, Zwick/Roell, Ulm, Germany) with maximum test load of $10 \mathrm{kN}$. The raw density of the boards (EN 323) was analysed with a density measuring system (DA-X, GreCon, Alfeld, Germany). Additional board properties such as moisture content (EN 322) and thickness swelling after $24 \mathrm{~h}$ water storage (EN 317) were investigated. For each type of board two panels were analysed. Sampling and cutting of the boards was accomplished as described in EN 326-1. The dimensions of the specimens were determined as described in EN 325.

\section{RESULTS AND DISCUSSION}

\section{Mechanical and Technological Properties of Wood-Based Panels}

Novel MDF boards composed of European beech and grand fir consistently showed higher internal bond strength than reference boards (Table 1). Novel wood-based panels even showed higher surface soundness than reference boards. Only MDF boards of beech displayed a lower bending strength than the reference. The bending strength has previously been studied in beech particleboards, and it was found that this parameter was strongly affected by particle size, surface layer compactness, and the coverage ratio of the particle surface with adhesive (Medved and Resnik 2004).

Table 1. Mechanical and Technological Properties of Novel and Conventional Wood-based Panels

\begin{tabular}{|l|c|c|c|c|c|c|c|}
\hline Tree species & $\begin{array}{c}\text { Type of } \\
\text { Panel board }\end{array}$ & $\begin{array}{c}\text { Thick- } \\
\text { ness } \\
(\mathrm{mm})\end{array}$ & $\begin{array}{c}\text { Raw } \\
\text { density } \\
\left(\mathrm{Kg} \mathrm{m}^{-3}\right)\end{array}$ & $\begin{array}{c}\text { Internal } \\
\text { bond } \\
\text { strength } \\
\left(\mathrm{N} \mathrm{mm}^{-2}\right)\end{array}$ & $\begin{array}{c}\text { Bending } \\
\text { strength } \\
\left(\mathrm{N} \mathrm{mm}^{-2}\right)\end{array}$ & $\begin{array}{c}\text { Surface } \\
\text { soundness } \\
\left(\mathrm{N} \mathrm{mm}^{-2}\right)\end{array}$ & $\begin{array}{c}\text { Swelling } \\
(24 \mathrm{~h}) \\
(\%)\end{array}$ \\
\hline $\begin{array}{l}\text { Reference } \\
\text { (Pine })\end{array}$ & MDF & 9 & 600 & 0.43 & 30.25 & - & 15.4 \\
\hline Grand fir & MDF & 9 & 600 & 0.65 & 34.52 & - & 15.3 \\
\hline Beech & MDF & 9 & 600 & 0.81 & 22.38 & - & 15.6 \\
\hline $\begin{array}{l}\text { Reference } \\
\text { (Spruce, Pine, } \\
\text { Beech) }\end{array}$ & $\begin{array}{c}\text { Particle- } \\
\text { board }\end{array}$ & 19 & 600 & 0.45 & 14.10 & 0.89 & 13.9 \\
\hline Grand fir & $\begin{array}{c}\text { Particle- } \\
\text { board }\end{array}$ & 19 & 600 & 1.27 & 18.13 & 1.72 & 12.6 \\
\hline
\end{tabular}

The mechanical and technical properties of three-layer particleboards of grand fir were better than those of reference boards produced from conventional chips (Table 1). 
The excellent values obtained here were most likely the result of the homogenous wood texture of Abies grandis (Alden 1997). A homogeneous wood texture probably causes low pile density of particles and fibres, improving the contact with the composite binder.

The swelling factors of all panels were almost identical to those of their respective reference (Table 1). Overall, these measurements indicate that spruce or pine-based production processes for MDF and particleboards can also be applied to beech and grand fir wood. This information is important, since there is currently little experience with the production of boards with other than conventional pine and spruce wood materials. Since beech silviculture is expanding in Germany, the amount of inferior beech wood will increase (Borchert and Kölling 2004; Horn 2006), and added-value products from these resources are needed. In addition to beech, grand fir wood was tested because this species is growing fast, is probably well adapted to the expected climate change (Hamann and Wang 2006), and forms non-resinous wood (Wagenführ 2000). In conclusion, our results did not reveal any major technical obstacles for the production of wood-based panels from European beech or grand fir.

\section{Chemical Changes during Production of Particleboards and MDF from Beech and Grand Fir}

To investigate chemical differences in wood of the two species and changes occurring during production processes, beech and grand fir wood, particles, fibres, and boards were characterized by FTIR spectroscopy. All major bands were numbered and the components to which these peaks were attributable are shown in Table 2.

A comparison of the wood spectra of grand fir (Fig. 1a) and European beech (Fig. 1b) shows that spectral similarities were high in the wavenumber range from 4000-1800 $\mathrm{cm}^{-1}$ and that differences occurred mainly in the fingerprint region $\left(1800-850 \mathrm{~cm}^{-1}\right)$.

Bands typical of holocellulose (no. 6, 8, 11, 12, 13, 19, and 20) were usually higher in beech than in grand fir. Pentosan determination and estimation of hemicellulose confirmed higher contents in beech $(25.4 \pm 1.5 \%)$ than in grand fir $(18.5 \pm 0.9 \%)$. Expected differences related to the absence of syringyl lignin in conifer compared with angiosperm wood were detected in bands 14,16 , and 17 . Overall these analyses illustrate that major differences between beech and grand fir wood existed with respect to lignin composition and holocellulose content, as reported previously for other conifers and angiosperms (Faix 1991; Pandey 1999; Pandey and Pitman 2003; Fengel and Wegener 2003; Pandey and Pitman 2004; Kubo and Kadla 2005; Fackler et. al 2007).

We identified a clear influence of the production process on wood chemistry (Figs. 1, 2). In addition to boards with a density of $600 \mathrm{~g} \mathrm{~m}^{-3}$, MDF and particleboards of higher densities were also analysed. However, board density had no effect on the resulting FTIR spectra (data not shown). Particles displayed higher absorbance in band 1, 6, 7, and 19 than wood, suggesting alterations in free OH-groups. These increases were found in particles from grand fir and beech (Fig. 1a,b) suggesting that the same chemical bonds were affected during particle production of both species. Similarly, these bands were also higher in fibres than in wood (Fig. 2a,b).

From the intermediate (particles, fibres) to the final product (board), further changes occurred, which were characteristic for wood from both species, but additionally some specific alterations for particle- or MDF boards were found. Band 1 increased 
further when particles or fibres were pressed to boards, whereas the intensities of bands 12,13 , and 19, indicative for holocellulose, decreased in boards compared to particles or fibres (Figs. 1, 2). Overall, these decreases were subtle but stronger in grand fir than in beech.

Table 2. Wavenumber Characterization (Usmanov et al. 1972; Parker 1983; Faix 1991; Faix 1992; Fengel and Wegener 2003; Pandey and Pitman 2003).

Numbers in the table refer to the numbers assigned to the bands in Figs. 1, 2, and 3 .

\begin{tabular}{|c|c|c|}
\hline $\begin{array}{l}\text { Wavenumber } \\
\left(\mathrm{cm}^{-1}\right)\end{array}$ & Compound & Band numbers \\
\hline 3336 & $\mathrm{O}-\mathrm{H}$ stretch & 1 \\
\hline 2938 & $\mathrm{CH}$ - stretch in methyl- and methylene groups & 2 \\
\hline 2882 & $\mathrm{CH}$ - stretch in methyl- and methylene groups & 3 \\
\hline 2103 & Absorption caused by the ATR crystal & 4 \\
\hline 1990 & Absorption caused by the ATR crystal & 5 \\
\hline 1738 & $\begin{array}{c}\mathrm{C}=\mathrm{O} \text { stretch in unconjugated ketones, carbonyls and in } \\
\text { ester groups (frequently of carbohydrate origin) }\end{array}$ & 6 \\
\hline 1649 & Absorbed $\mathrm{O}-\mathrm{H}$ and conjugated $\mathrm{C}-\mathrm{O}$ & 7 \\
\hline 1593 & Aromatic skeletal vibration plus $\mathrm{C}=\mathrm{O}$ stretch & 8 \\
\hline 1549 & Secondary amides (-CO-NH-) & 9 \\
\hline 1505 & Aromatic skeletal vibration plus $\mathrm{C}=\mathrm{O}$ stretch & 10 \\
\hline 1460 & $\mathrm{CH}$ - deformation; asymmetric in $-\mathrm{CH}_{3^{-}}$and $-\mathrm{CH}_{2-}^{-}$ & 11 \\
\hline 1424 & $\begin{array}{c}\text { Aromatic skeletal vibration combined with } \mathrm{CH} \text { in plane } \\
\text { Deformation }\end{array}$ & 12 \\
\hline 1372 & $\mathrm{CH}$ deformation in cellulose and hemicellulose & 13 \\
\hline 1328 & $\mathrm{~S}$ ring plus $\mathrm{G}$ ring condensed & 14 \\
\hline 1318 & $\begin{array}{l}\text { C-H vibration in cellulose and } \mathrm{C}-\mathrm{O} \text { vibration in syringyl } \\
\text { derivates }\end{array}$ & 15 \\
\hline 1267 & $\begin{array}{c}\text { Guaiacyl ring breathing, C-O stretch in lignin; C-O linkage in } \\
\text { guaiacyl aromatic methoxy groups }\end{array}$ & 16 \\
\hline 1235 & Syringyl ring and $\mathrm{C}=$ stretch in lignin and xylan & 17 \\
\hline 1157 & $\mathrm{C}-\mathrm{O}-\mathrm{C}$ vibration in cellulose and hemicellulose & 18 \\
\hline 1032 & $\begin{array}{c}\text { Aromatic } \mathrm{C}-\mathrm{H} \text { in plane deformation, guaiacyl type and } \mathrm{C}-\mathrm{O} \\
\text { deformation; primary alcohol }\end{array}$ & 19 \\
\hline 897 & $\beta$-glycosidic linkages, besides $\mathrm{CH}$-deformation of cellulose & 20 \\
\hline
\end{tabular}

During the production process of wood composites intermediate products are exposed to elevated temperatures, e.g. during pressing of wood panels. However, these temperatures are below those reported to lead to weight loss of cellulose or hemicellulose ( $>200^{\circ} \mathrm{C}$, Rowel and LeVan-Green 2005). Nevertheless, changes in the extent of polymerisation can occur at lower temperatures and were already found at $180{ }^{\circ} \mathrm{C}$ (Sivonen et al. 2002; Garrote et al. 2001). The slight deviations in the spectra of particles (Fig. 1) and fibres (Fig. 2) might have been caused by dehydrogenation, which would be expected to increase the number of $-\mathrm{OH}$, and thus lead to the observed increases in absorbance at position $1032 \mathrm{~cm}^{-1}$ (Figs. 1, 2). The distinct declines of the absorbance units at $1738 \mathrm{~cm}^{-1}$ and $1032 \mathrm{~cm}^{-1}$ (bands 6 and 19) of the spectra of all final products compared with fibres and particles was a further indication for modifications of the 

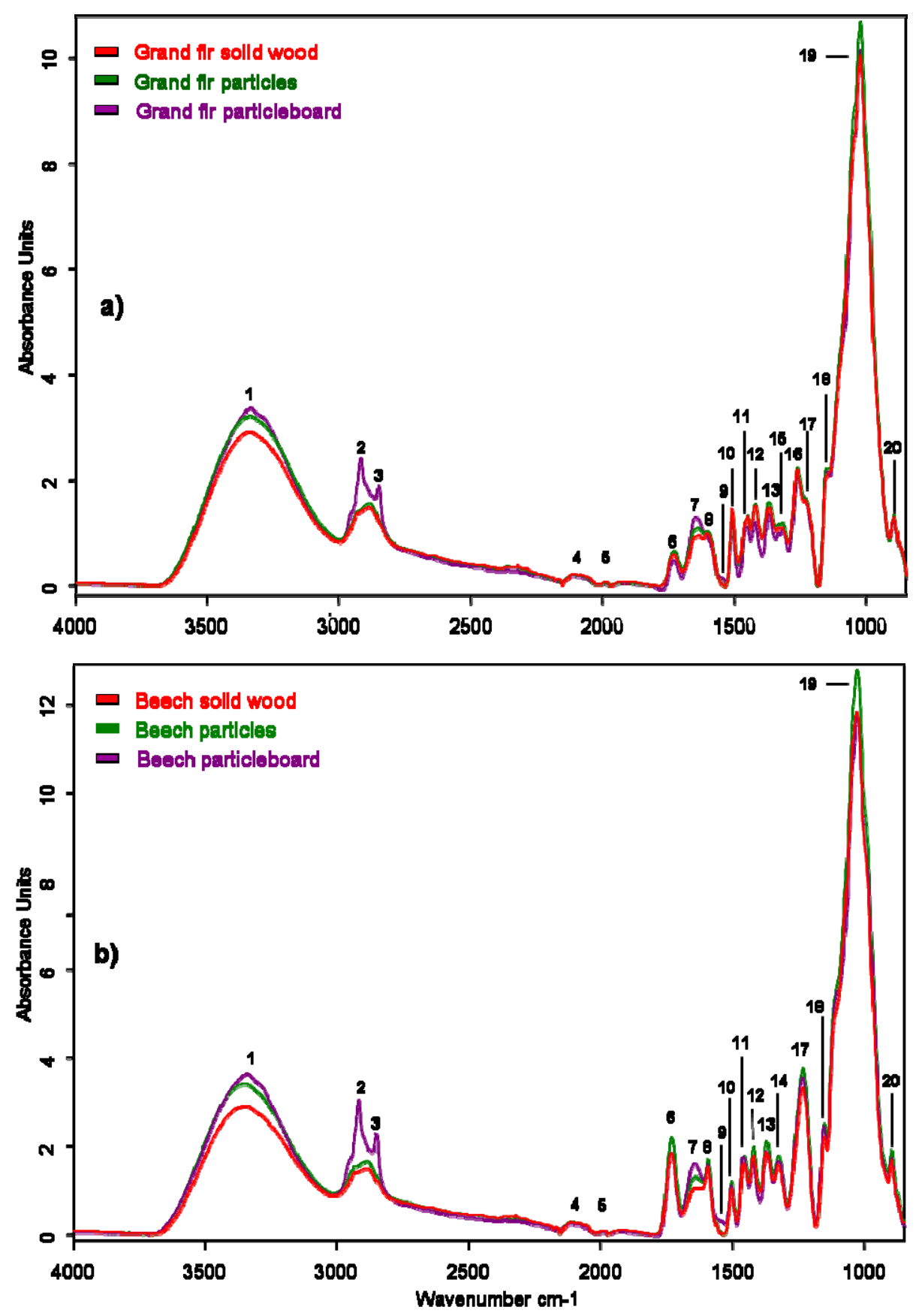

Fig. 1. FTIR-ATR mean spectra of wood, particles and particleboards of grand fir (a) and beech (b). Spectra were acquired in the wavenumber range from $4000-850 \mathrm{~cm}^{-1}(\mathrm{n}=10$ per sample), and the mean was calculated. Particleboards of $\rho=600 \mathrm{~kg} \mathrm{~m}^{-3}$ are shown. The spectra were baseline corrected and vector normalised; the band assignments refer to Table 2 . 

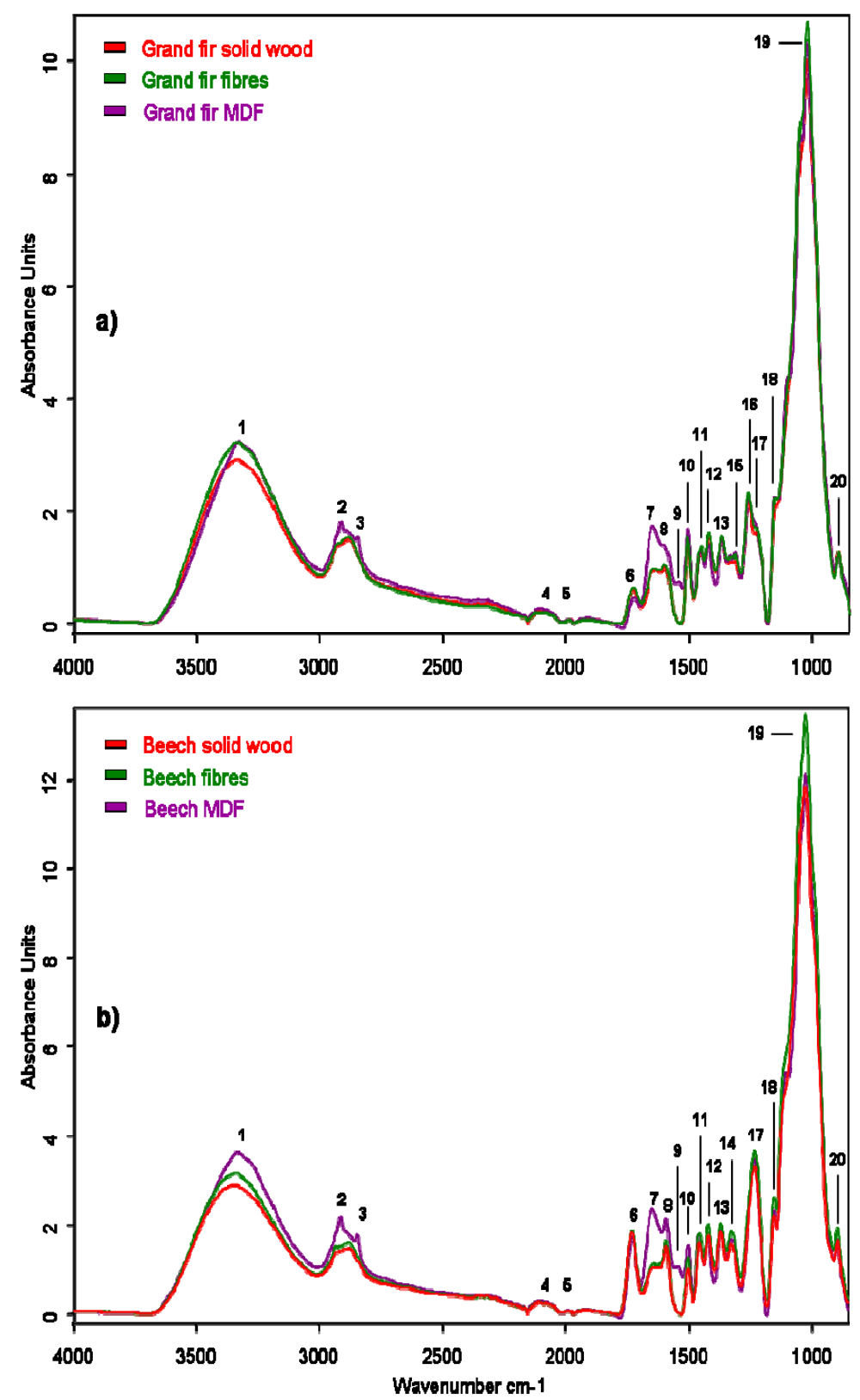

Fig. 2. FTIR-ATR mean spectra of fibres and MDF boards of grand fir (a) and beech (b). Spectra were acquired in the wavenumber range from $4000-850 \mathrm{~cm}^{-1}(\mathrm{n}=10$ per sample), and the mean was calculated. Spectra of solid wood powder from Fig. 1 are shown for comparison. MDF boards of $\rho=600 \mathrm{~kg} \mathrm{~m}^{-3}$ are shown. The spectra were baseline corrected and vector normalised; the band assignments refer to Table 2 . 
holocellulose fraction during panel board processing (Figs. 1, 2). To investigate changes in the carbohydrate fraction occurring during panel board production, we conducted pentosan measurements in wood, fibres, and MDF boards of beech and grand fir (Table 3).

Table 3. Pentosan Concentrations in Wood, Fibres, and MDF Boards Produced from Beech (Fagus sylvatica L.) and Grand Fir (Abies grandis). Data are means of three replicates ( \pm standard deviation).

\begin{tabular}{|c|c|c|}
\hline Material & \multicolumn{2}{|c|}{ Pentosan (\%) } \\
\hline & Beech & Grand Fir \\
\hline Wood & $19.6 \pm 0.1$ & $9.2 \pm 0.2$ \\
\hline Fibre & $14.7 \pm 0.1$ & $9.1 \pm 0.2$ \\
\hline MDF & $18.8 \pm 0.3$ & $11.1 \pm 0.3$ \\
\hline
\end{tabular}

As anticipated in both species, the pentosan fraction was lower in fibres than in wood. Fengel (1966) reported decreases in pentosan after thermal treatment of conifer wood at temperatures above $160^{\circ} \mathrm{C}$ to $180^{\circ} \mathrm{C}$. Hennecke and Roffael (2006) also found a decomposition of hemicellulose to lower molecular weight sugars during the pulping of fibres under thermal-mechanical conditions.

In addition to changes in carbohydrate structure, novel bands (bands 2, 3, and 9) appeared in the final products, and band 7, which was only present as a shoulder in wood, particles, or fibres, was increased to a pronounced peak in panel boards (Figs. 1, 2). To obtain information on the chemical nature of novel peaks, the spectra of boards were compared with those of the binders used (UF-resins) and of the water-repellent additives $\left(\right.$ HydroWax $^{\circledR}$ ) (Fig. 3). Bands 2 and 3 were characteristic of HydroWax ${ }^{\circledR}$ (Fig. 3).

Since these peaks were also present in pure paraffin (not shown), they can be used to trace the presence of wax. In a previous work, Garcia et al. (2006) studied MDF boards from fibres treated with a maleated polypropylene wax, commercially called Epolene E43P, and identified FTIR peaks at the same positions as band 2 and 3 in our study. This clearly shows that waxes added to improve the dimension stability by acting as antiwetting agents can easily be detected in wood products, regardless their commercial formulation.

The presence of UF resin was also immediately apparent from the FTIR spectra of MDF and particleboards. This was previously reported by Körner et al. (1992), investigating industrial-processed particleboards with FTIR spectroscopy. They detected significant bands of pure UF resin in the same wavenumber range as in our study with a pronounced peak at $3363 \mathrm{~cm}^{-1}$ (band 1 in Fig 3), which they assigned tentatively to $\mathrm{O}-\mathrm{H}$ and N-H vibrations (Körner et al. 1992). Körner et al. (1992) found a further band at $1704 \mathrm{~cm}^{-1}$ in the spectrum of pure UF resin, which was assigned to formaldehyde. In our study, this band was missing in the spectra of pure K 350 and K 413, as well as in those of the boards.

Band 9 at wavenumber $1549 \mathrm{~cm}^{-1}$ was only detectable in the final products (Figs. 1, 2). According to Körner et al. (1992) this band was caused by secondary amides (-CO$\mathrm{NH}-)$, resulting from a modification of pure urea $\left(-\mathrm{CO}\left(\mathrm{NH}_{2}\right)_{2}\right)$ as a component of UF resin. In our study band 9 was higher in spectra of MDF than in those of particleboards 
(Figs. 1, 2). This was probably caused by differences in the content and composition of the applied binder. Correlations between the coverage of fibres with adhesives and the portion of resin in MDF boards of spruce and aspen have been reported (Pakdel et al. 2008). Our study furthermore shows that the absorbance increases at positions 9 and 7 were much higher in MDF than in particleboard spectra (Figs. 2, 4). This was probably related to the utilization of two types of UF resin: $\mathrm{K} 413$ used for MDF production comprised a higher fraction of urea than $\mathrm{K} 350$ and contained melamine $\left(\mathrm{C}_{3} \mathrm{H}_{6} \mathrm{~N}_{6}\right)$ as a further additive. Spectroscopic investigations of both binders revealed consistently higher absorbance units for K 413 than for K350 (Fig. 3). These analyses confirm that adhesives and other additions can be traced in the resulting products and show that resins with similar properties like K413 and K430 can be distinguished in wood products.

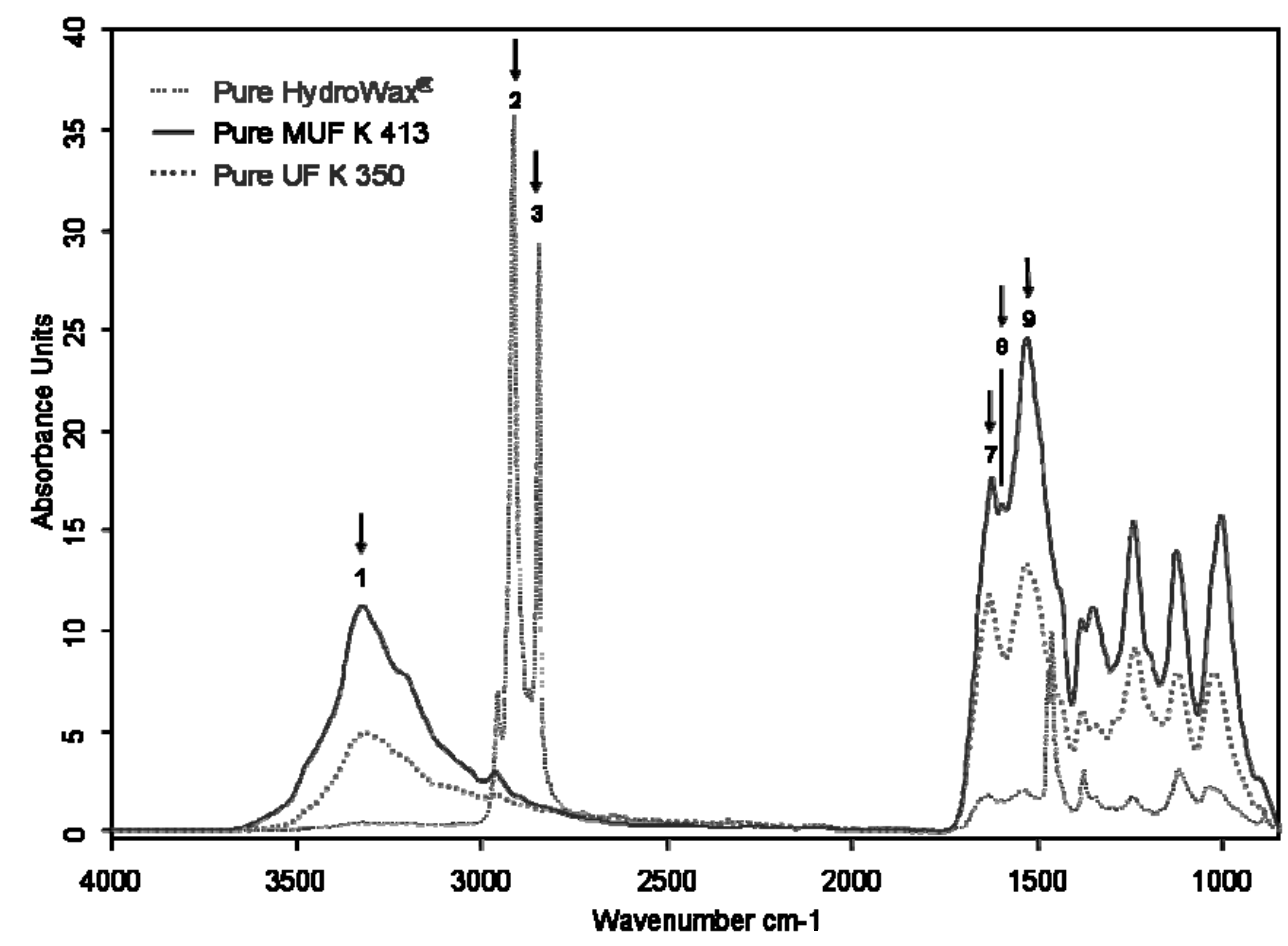

Fig. 3. FTIR-ATR averaged spectra of MUF K 413, UF K 350 and HydroWax ${ }^{\circledR}$ in the wavenumber range from $4000-850 \mathrm{~cm}^{-1}$. The spectra were baseline corrected and vector normalised. The bands showing the most significant influences in the spectra of the final products were marked. Band assignments are shown in Table 2.

FTIR spectra of all production steps were distinguished by differences in absorbance at $1596 \mathrm{~cm}^{-1}$ (position 8). This position is indicative for aromatic $\mathrm{C}=\mathrm{O}$ stretch vibrations and thus may point to changes in furfural concentrations. Furfural is formed by dehydrogenation of pentoses. Under acidic conditions and high temperatures, pentoses can be transformed into furfural. During the pressing process the surface of the boards can reach temperatures of $200^{\circ} \mathrm{C}$ (Deppe and Ernst 2000; Ohlmeyer 2002), which might have led to an opening of the C-O bonds of polyose residues (Kollmann and Fengel 1965; Bourgois and Guyonnet 1988) and resulted in furfural formation. 


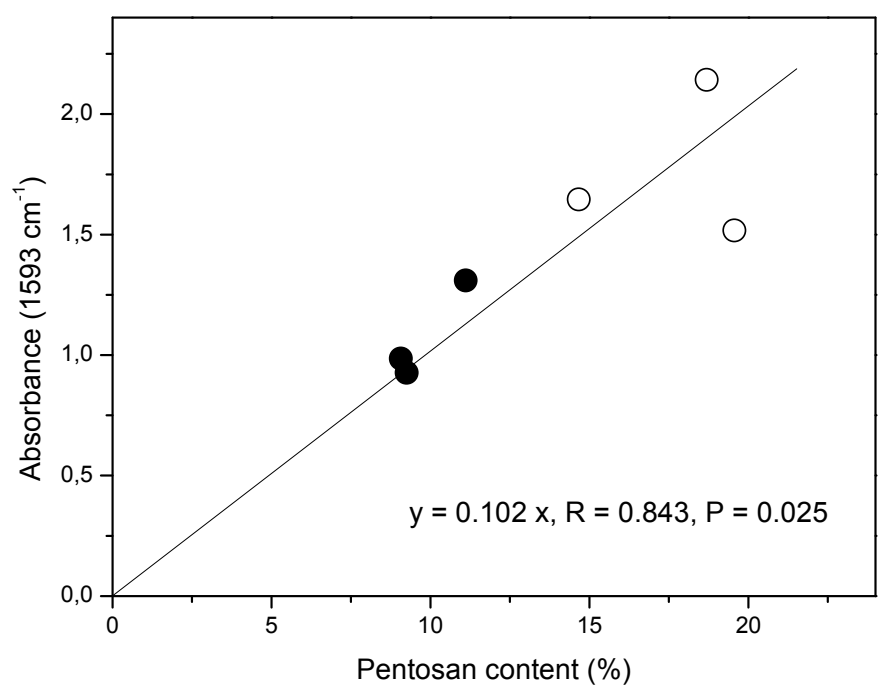

Fig 4. Correlation of measured pentosan concentrations in wood, fibres and MDF boards of grand fir (black symbols) and beech (open symbols) with the absorbance at $1593 \mathrm{~cm}^{-1}$ in FTIR spectra.

The formation of furfural during board production is probably the reason for the increased pentosan contents measured in boards (Table 3). The absorbance at $1596 \mathrm{~cm}^{-1}$ showed a highly significant correlation with pentosan concentrations (Fig. 4). Overall, this indicates that the processing of wood caused modifications of hemicellulose, resulting in increased furfural concentrations in MDF boards, and that these changes can be detected in FTIR-ATR spectra.

\section{Multivariate Analysis of FTIR Spectra to Elucidate Product Quality and Properties}

PCA was conducted to find out if the different samples could be grouped according to species and sample processing. Using normalised first derivatives of the original spectra across the whole wavenumber range, we obtained four PCAs, which contributed 92.97, 5.76, 0.97, and $0.19 \%$ to the total variation, respectively. Since PC1 resembled strongly the original spectrum, it was not considered further. A 3-dimensional scatter plot showed that the 10 different sample types (2 tree species with the following products: wood, fibres, particles, MDF, and particleboards) grouped according to PC2, PC3, and PC4 (Fig. 5). PC2 was mainly responsible for the separation of the two species: Grand fir products (wood, fibres, particles, MDF and particleboards) scored positive, whereas the corresponding beech products had negative scores for PC2 (Fig. 5). PC3 separated final products of both species (MDF and particleboards, negative scores) from raw and intermediate materials of both species (wood, fibres and particles, positive scores).

PC4 was mainly responsible for the separation of fibres, particles, and wood, with fibres showing more negative scores than particles and particles more negative than wood (Fig. 5). Fibres, particles, and wood showed some overlap, but the gross groups were still discernable. 


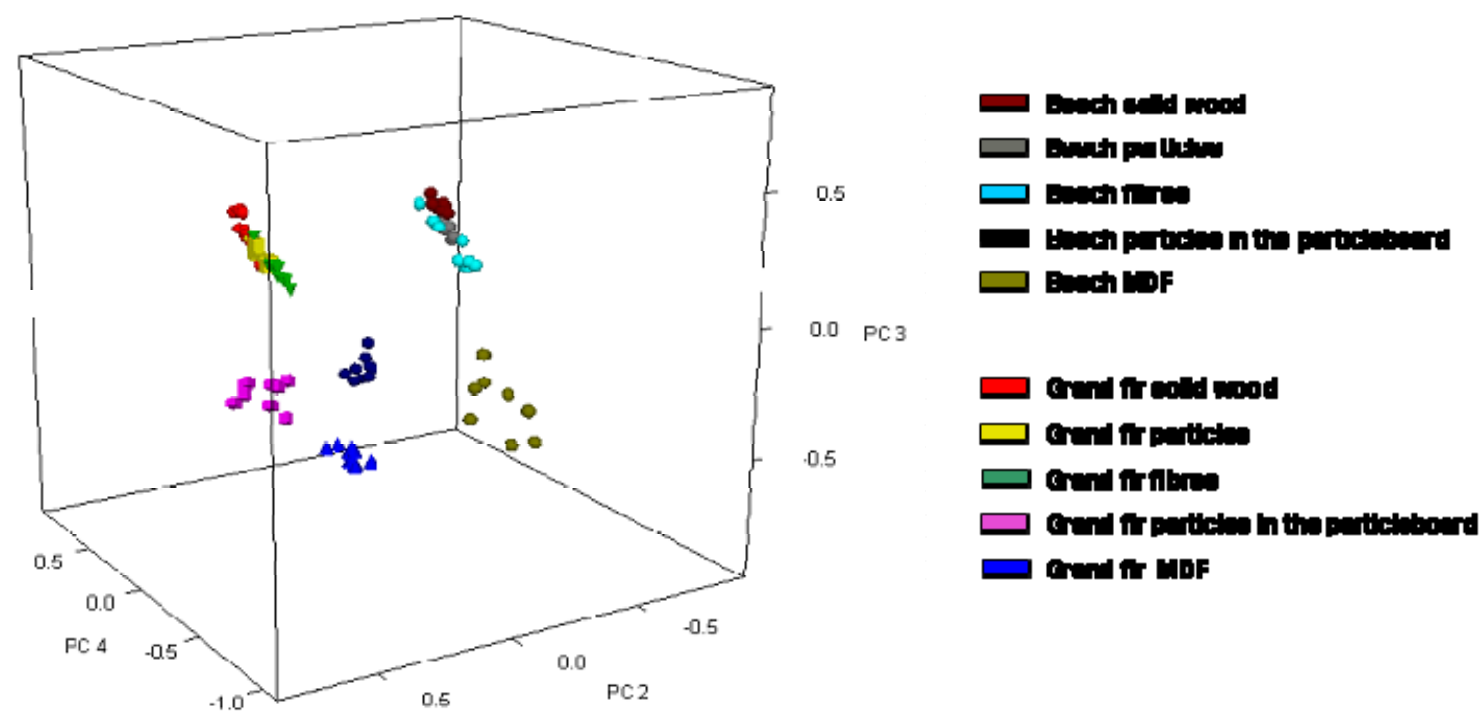

Fig. 5. Principal component analysis (PCA) for the FTIR-ATR spectra of the different production steps of beech and grand fir wood. Spectra were used in the wavenumber range from 4500-600 $\mathrm{cm}^{-1}$. First derivation and vector normalization have been used as pre-treatment of the spectra. For the factorisation 9 smoothing points and 3 factors have been chosen.

To elucidate which spectral differences were mainly for responsible for the separation of the groups, factor loadings were determined. The 10 major peaks of the factor loadings of each PC were assigned to their tentative chemical origin using published data (Table 4).

It is immediately apparent that compounds representing lignin (e.g. position 1, 3, 5, 6, 8 among them syringyl ring breathing at position 3, Table 4) played a major role in PC2, which separated the two species (Fig. 5). In PC3, wavenumbers indicative of lipophilic compounds (wax) as well as for $\mathrm{N}$-containing compounds (resins) were dominant as reasons for the separation of boards from raw and intermediate products (Table 4). In PC4 similar wavenumbers were dominant as in PC3, though in slightly different order. In addition, position 9 and 10 indicated the contribution of $\mathrm{C}=\mathrm{C}$ aromatic bonds to this factor (Table 4).

While PCA is a data reduction technique that maps the main components of the spectra in scatter-plots and, thus, allows identification of the spectral origin leading to the formation of groups (McCann et al. 1997), cluster analysis classifies the intrinsic interrelationship between structure and property of samples (Everitt 1993). Cluster analysis can be used to assess the similarity or dissimilarity between samples, and therefore, is useful to assess the quality of production processes. We subjected the spectral data of all samples to cluster analysis and calculated their heterogeneity. We tested different calculation methods (nearest neighbour, furthest neighbour, Centroid, median, Ward's) and obtained the best results using Ward's method for calculation of the distance matrix, based on Euclidean distance. Using this approach, we received two main sub-clusters separating both tree species, beech and grand fir, respectively (Fig. 6). These clusters were split in two further $2^{\text {nd }}$ order sub-clusters. 
Table 4. Wavenumber Characterization (according to Usmanov et al. 1972; Parker 1983; Faix 1992; Naumann et al. 1991; Fengel and Wegener 2003; Pandey and Pitman 2003; Williams 2005) of the second (PC2), third (PC3), and fourth (PC4) factor loadings obtained by PCA. The zero-points between the 10 most pronounced valleys and hills, representing the 10 main peaks, were tentatively assigned to their chemical origin. The numbers in parenthesis indicate the position in Fig. 6.

\begin{tabular}{|c|c|c|c|}
\hline \multicolumn{3}{|c|}{$\begin{array}{l}\text { Wavenumber } \\
\left(\mathrm{cm}^{-1}\right)\end{array}$} & \multirow[t]{2}{*}{ Compound } \\
\hline $\begin{array}{c}2^{\text {nd }} \\
\text { Factor }\end{array}$ & $\begin{array}{l}3^{\text {rd }} \\
\text { Factor }\end{array}$ & $\begin{array}{l}4^{\text {th }} \\
\text { factor }\end{array}$ & \\
\hline $1122(1)$ & & & Aromatic skeletal and C-O stretch \\
\hline $1042(2)$ & & & C-O stretch \\
\hline $1235(3)$ & & & Syringyl ring, C-O stretch in lignin and xylan \\
\hline $1016(4)$ & & & $\mathrm{C}-\mathrm{OH}$ in alcohols \\
\hline $1143(5)$ & & & $\mathrm{C}-\mathrm{H}$ in plane deformation of guaiacyl ring, $\mathrm{O}-\mathrm{H}$ in lignin \\
\hline $1272(6)$ & & & Guaiacyl ring breathing \\
\hline $1061(7)$ & & & $\mathrm{C}-\mathrm{C}, \mathrm{C}-\mathrm{O}, \mathrm{C}=\mathrm{O}$ stretching in cellulose and hemicellulose \\
\hline $1513(8)$ & & & Aromatic skeletal vibration in lignin \\
\hline $974(9)$ & & & $-\mathrm{HC}=\mathrm{CH}$ - out-of-plane deformation \\
\hline $1733(10)$ & & & $\begin{array}{c}\mathrm{C}=\mathrm{O} \text { stretch in } \mathrm{COOH}, \mathrm{C}=\mathrm{O} \text { stretch in unconjugated } \\
\text { ketones, carbonyls and in ester groups (frequently of } \\
\text { carbohydrate origin) }\end{array}$ \\
\hline & $1074(1)$ & & C-H, C-O deformation \\
\hline & $2920(2)$ & & Methylene and methine group \\
\hline & $1055(3)$ & & C-O stretch in cellulose and hemicellulose \\
\hline & $2850(4)$ & & $\mathrm{C}-\mathrm{H}$ stretch in $\mathrm{CH}_{3}$ and $\mathrm{CH}_{2}$ groups, $\mathrm{N}-\mathrm{H}$ \\
\hline & $2878(5)$ & & $\mathrm{C}-\mathrm{H}$ stretch in $\mathrm{CH}_{3}$ and $\mathrm{CH}_{2}$ groups, $\mathrm{N}-\mathrm{H}$ \\
\hline & $1680(6)$ & & $\mathrm{C}=\mathrm{O}$ stretch in conjugated ketones and secondary amides \\
\hline & $1108(7)$ & & $\mathrm{C}-\mathrm{O}-\mathrm{C}, \mathrm{C}-\mathrm{O}$ dominated by ring vibration of carbohydrates \\
\hline & $992(8)$ & & $-\mathrm{HC}=\mathrm{CH}-$ out-of-plane deformation \\
\hline & $1030(9)$ & & $\begin{array}{c}\text { Aromatic } \mathrm{C}-\mathrm{H} \text { in plane deformation, guaiacyl type and } \mathrm{C}-\mathrm{O} \\
\text { deformation; primary alcohol }\end{array}$ \\
\hline & $2947(10)$ & & O-H vibration \\
\hline & & $2920(1)$ & Methylene and methine group \\
\hline & & $1074(2)$ & C-H, C-O deformation \\
\hline & & $2852(3)$ & $\mathrm{C}-\mathrm{H}$ stretch in $\mathrm{CH}_{3}$ and $\mathrm{CH}_{2}$ groups, $\mathrm{N}-\mathrm{H}$ \\
\hline & & $2878(4)$ & $\mathrm{C}-\mathrm{H}$ stretch in $\mathrm{CH}_{3}$ and $\mathrm{CH}_{2}$ groups, $\mathrm{N}-\mathrm{H}$ \\
\hline & & $1050(5)$ & $\mathrm{C}-\mathrm{O}$ stretch in polysaccharides \\
\hline & & $1114(6)$ & $\mathrm{O}-\mathrm{H}$ association band in cellulose and hemicellulose \\
\hline & & $1032(7)$ & $\begin{array}{l}\text { Aromatic } \mathrm{C}-\mathrm{H} \text { in plane deformation, } \mathrm{C}-\mathrm{O} \text { in prim. Alcohols, } \\
\qquad \mathrm{C}=\mathrm{O} \text { stretch }\end{array}$ \\
\hline & & $1747(8)$ & Non-conjugated carbonyl \\
\hline & & $1500(9)$ & Aromatic $\mathrm{C}=\mathrm{C}$ \\
\hline & & $974(10)$ & $-\mathrm{HC}=\mathrm{CH}$ - out-of-plane deformation \\
\hline
\end{tabular}




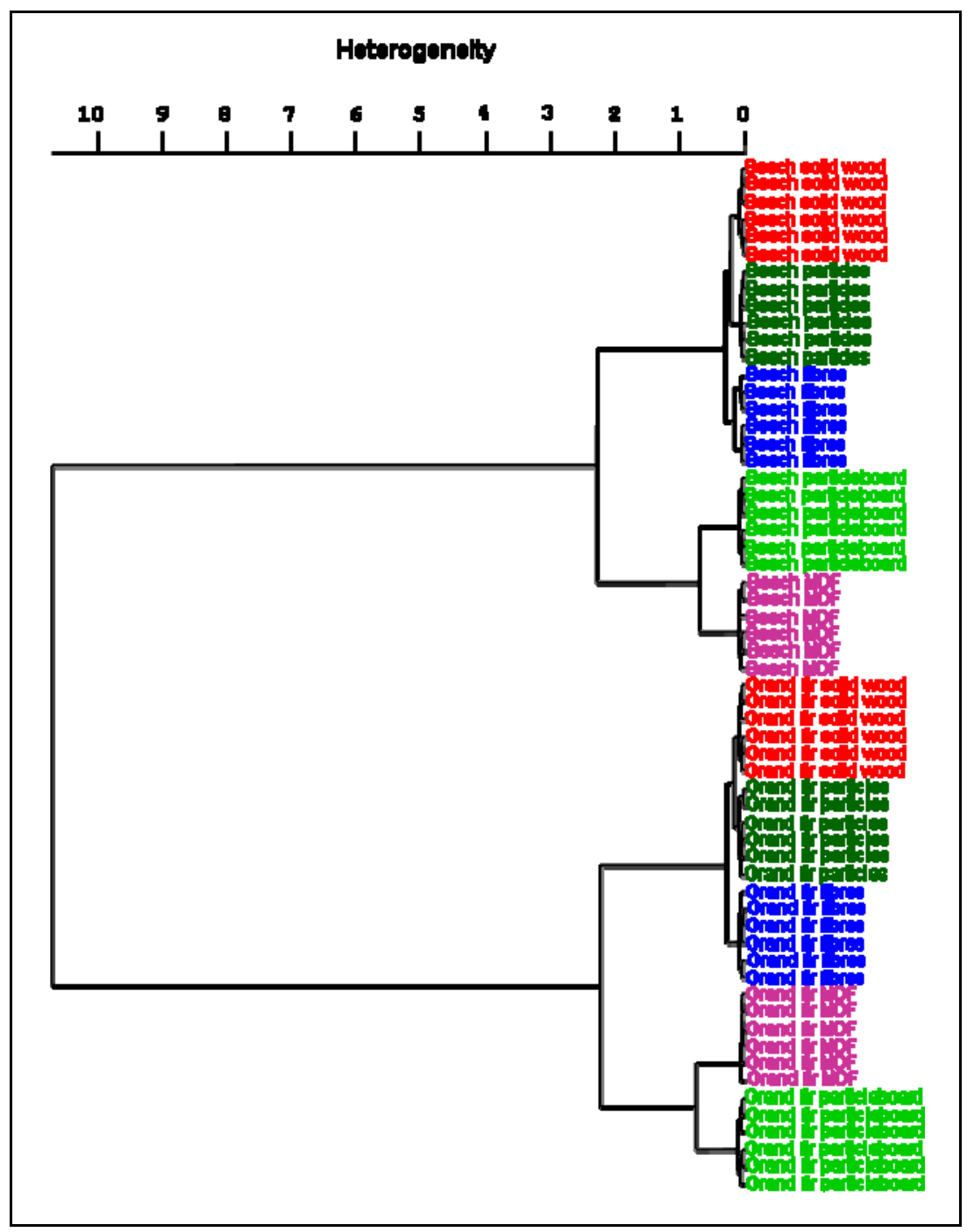

Fig. 6. Cluster analysis of FTIR-ATR spectra of samples of wood, fibres, particles, particleboards and MDF boards of beech and grand fir. Spectral data were used in the wavenumber range from $2968-841 \mathrm{~cm}^{-1}$ and classified into classes according to their spectral heterogeneity. The first derivation and vector normalization was utilized as pre-treatment method of the spectra. For clarity, only 6 of 10 spectra have been shown for each production step. Spectra, which have not been shown, clustered in their respective groups. The different production steps have been indicated in different colours.

Each of these $2^{\text {nd }}$ order sub-clusters separated raw material and intermediate products in one $3^{\text {rd }}$ order and the final products in the other $3^{\text {rd }}$ order sub-cluster. This shows the low spectral heterogeneity among raw materials and intermediate wood products. Still, there were sufficiently large spectral differences between raw materials, intermediate and final products, to yield $4^{\text {th }}$ order sub-clusters. The same was true for the end products, MDF and particleboards, respectively. The heterogeneity between the $4^{\text {th }}$ order sub-clusters of raw and intermediate products was much lower than that observed for final products. 


\section{CONCLUSIONS}

In this study we demonstrated the potential of FTIR spectroscopy combined with multivariate data analysis to characterise the whole production process of wood to fibreand particleboards, starting with the raw material harvested in the forest. We used European beech and grand fir wood as novel raw materials for wood-based panels and documented that boards from these materials comply with the requirements of European standards.

1. Species-specific chemical characteristics were maintained throughout all production steps, affording very clear separation of particleboards or MDF made of beech or grand fir wood. Based on the results of PCA and factor loadings we conclude that the production process has no major influence on the chemical constituents that distinguish soft- and hardwoods.

2. It was possible to differentiate FTIR spectra obtained for wood, fibres, and particles. Each production step introduced specific modifications that affected FTIR spectra in a specific manner. Therefore, spectroscopic changes in the infrared can be used to identify changes of the chemical constituents during wood-based panel board manufacturing, especially when combined with PCA.

3. Different samples from the same production step were clustered together, suggesting a high homogeneity of the raw materials as well as of the resulting intermediate and final products. This indicates that FTIR spectroscopy in combination with cluster analysis is a tool to control product quality if standards were available. Since the beech and grand fir boards produced in this study showed mechanical and technological properties similar to those from conventional production processes, standardisation and application of this novel methodology is promising and should be further developed.

\section{ACKNOWLEDGEMENTS}

We are grateful to the Federal Ministry of Education and Research (BMBF, Projektträger Jülich PTJ) for financial support of the project "Innovation durch spektroskopisch-bildanalytisch kontrollierte Produktionsprozesse für Holzwerkstoffe" through the programme "Nachhaltige Waldwirtschaft". We thank Prof. Dr. Spellmann (Nordwestdeutsche Forstliche Versuchsanstalt, Göttingen) and Prof. Dr. Thole (WilhelmKlauditz Institut, Braunschweig) for providing the solid wood, fibres, and particles of beech and grand fir. 


\section{REFERENCES CITED}

Alden, H. A. (1997). “Softwoods of North America,” Gen. Tech. Rep.-102US, Department of Agriculture, Forest Service, Forest Products Laboratory, ed., Madison, Wisconsin, (http://www2.fpl.fs.fed.us/publications/fplgtr102.pdf ).

Alteheld, R. (2007). "Veränderte Stoffströme bei Sägeresthölzern: Auswirkungen auf den Holzmarkt,” Kongress Rohholzmanagement in Deutschland, Hannover, (http://www.kompetenznetz-holz.de/aktuelles/rohholzmanagement/vortraege/ 11_Referat_Alteheld.pdf).

Ambrozy, H. G., and Giertlova, Z. (2005). Planungshandbuch Holzwerkstoffe: Technologie-Konstruktion-Anwendung, Springer Verlag, Wien.

Augustin, H., and Puls, J. (1982). "Perspectives on the production of chemicals from wood (in Western Europe),” Timber Bulletin for Europe, FAO, Geneva.

Arndt, K. F., Richter, A., Ludwig, S., Zimmermann, J., Kressler, J., Kuckling, D., and Adler, H. J. (1999). "Poly(vinyl alcohol)/poly(acrylic acid)hydrogels: FT-IR spectroscopic characterisation of crosslinking reaction and work at transition point," Acta Polymerica 50(11-12), 383-390.

BASF AG (2008). Technisches Merkblatt für Leime und Tränkharze für die Holzwerkstoff- Industrie. Kaurit® Leim 350 flüssig, Nr. M 5884 d, Februar 2008.

BASF AG (2008). Technisches Merkblatt für Leime und Tränkharze für die Holzwerkstoff- Industrie. Kaurit ${ }^{\circledR}$ Leim 413 flüssig, Nr. M 6290 d, Februar 2008

BASF AG (2008). Technisches Merkblatt für Leime und Tränkharze für die Holzwerkstoff- Industrie. Kaurit ${ }^{\circledR}$ Leim 465 flüssig, Nr. M 6176 d, Februar 2008

Behrendt, S., and Rupp, J. (2006). "Perspektiven der Holzmobilisierung zur Stärkung nachhaltiger Zukunftsmärkte der Forst- und Holzwirtschaft,” Paperreihe des Holzwende 2020plus-Projektes, Institut für Zukunftsstudien und Technologiebewertung, ed., Eigenverlag, Berlin, (http://www.holzwende2020.de/ custom/user/Basis-Studie/Perspektiven_Holzmobilisierung.pdf)

Behrendt, S., Henseling, C., Erdmann, L., Knoll, M., and Rupp, J. (2007). “Trendreport: Zukunftstrends für das Bauen mit Holz,” Paperreihe des Holzwende 2020plusProjektes, Institut für Zukunftsstudien und Technologiebewertung, ed., Eigenverlag, Berlin, (http://www.holzwende2020.de/custom/user/Basis-Studie/Trendreport_IZT .pdf)

Borchert, H., and Kölling, C. (2004). "Waldbauliche Anpassung der Wälder an den Klimawandel jetzt beginnen,” LWF Aktuell 43, 28-30.

Bourgois, J., and Guyonnet, R. (1988). "Characterization and analysis of torrefied wood,” Wood Science and Technology 22(2), 143-155.

Bukowski, E. J., and Monti, J. A. (2007). "FTIR-ATR spectroscopy for identification of illicit drugs seized from clandestine laboratories,” American Laboratory 39(20), 1619.

Deppe, H.-J., and Ernst, K. (2000). Taschenbuch der Spanplattentechnik, DRW Verlag, Leinfelden-Echterdingen.

Dohrenbusch, A., and Bolte, A. (2008). "Forest plantations," Wood Production, Wood Technology and Bio-Technological Impacts, U. Kües, ed., Universitätsverlag, Göttingen. 
Ellenberg, H. (1996). Vegetation Mitteleuropas mit den Alpen in ökologischer Sicht, Eugen Ulmer Verlag, Stuttgart.

European standard EN 310 (1993). "Wood-based panels; Determination of modulus of elasticity in bending and of bending strength,” European Committee for Standardisation, Brussels, Belgium.

European standard EN 311 (2002). "Wood-based panels - Surface soundness - Test method, European Committee for Standardisation,” Brussels, Belgium.

European standard EN 317 (1993). "Particleboard and fibreboards; Determination of swelling in thickness after immersion in water,” European Committee for Standardisation, Brussels, Belgium.

European standard EN 319 (1993). "Particleboard and fibreboards; Determination of tensile strength perpendicular to the plane of the board," European Committee for Standardisation, Brussels, Belgium.

European standard EN 322 (1993). "Wood-based panels; Determination of moisture content,” European Committee for Standardisation, Brussels, Belgium.

European standard EN 323 (1993). "Wood-based panels; Determination of density," European Committee for Standardisation, Brussels, Belgium.

European standard EN 325 (1993). "Wood-based panels; Determination of dimensions of test pieces,” European Committee for Standardisation, Brussels, Belgium.

European standard EN 326-1 (1994). "Wood-based panels; Sampling, cutting and inspection - Part 1: Sampling and cutting of test pieces and expression of test results,” European Committee for Standardisation, Brussels, Belgium.

Everitt, B. S. (1993). Cluster Analysis, John Wiley, Toronto.

Fabo, A. (2004). "Untersuchungen zur Wechselwirkung von Polyethylenimin (PEI) mit Holzkomponenten,” Dissertation, Universität Hamburg, Hamburg, Germany.

Fackler, K., Schwanninger, M., Gradinger, C., Srebotnik, E., Hinterstoisser, B., and Messner, K. (2007). "Fungal decay of spruce and beech wood assessed by nearinfrared spectroscopy in combination with uni- and multivariate data analysis," Holzforschung 61, 680-687.

Faix, O. (1991). "Classification of lignins from different botanical origins by FT-IR spectroscopy,” Holzforschung 45(Suppl.), 21-27.

Faix, O. (1992). "Fourier transform infrared spectroscopy," Methods in Lignin Chemistry, S. Y. Lin, C. W. Dence (eds.), Springer, Berlin.

Fengel, D. (1966). “Über die Veränderung des Holzes und seiner Komponenten im Temperaturbereich bis $200{ }^{\circ} \mathrm{C}$. Zweite Mitteilung: Die Hemicellulosen in unbehandeltem und thermisch behandeltem Fichtenholz," Holz als Roh- und Werkstoff 24(3), 98-109.

Fengel, D., and Wegener, G. (2003). Wood - Chemistry, Ultrastructure Reactions, Kessel Verlag, Remagen.

Garcia. R. A., Cloutier, A., and Riedl, B. (2006). “Chemical modification and wetting of medium density fibreboard panels produced from fibres treated with maleated polypropylene wax,” Wood Science and Technology 40, 402-416.

Garrote, G., Dominguez, H., and Parajo, J. C. (2001). "Study on the deacetylation of hemicellulose during the hydrothermal processing of Eucalyptus wood," Holz als Roh- und Werkstoff 59(1-2), 53-59. 
Hamann, A., and Wang, T. (2006). "Potential effects of climate change on ecosystem and tree species distribution in British Columbia,” Ecology 87(11), 2773-2786.

Hennecke, U., and Roffael, E. (2006). "Veränderungen der chemischen Eigenschaften von Fasern und MDF durch Waschen der aufgeschlossenen Fasern,“ Holz als Rohund Werkstoff 64(4), 305-311.

Holzwirtschaft Schweiz. (2007). Holz in Bestform, HWS-Holzwerkstoffe Schweiz, (ed.), Kalt-Zehnder, Zug, (http://www.holzhandelszentrale.ch/pdf/hws bestform_d.pdf).

Horn, O. (2006). "Mischung stützt Nadelholz-Klimawandel und Borkenkäfer beeinflussen die Baumartenwahl,“ Bayerisches landwirtschaftliches Wochenblatt 43, Deutscher Landwirtschaftsverlag, Hannover.

Jayme, G., and Büttel H. (1968). "Vergleich verschiedener Verfahren zur Pentosanbestimmung einschließlich einer neuen ISO-Methode,” Das Papier 22(5), 249-253.

Kacuráková, M., and Wilson, R. H. (2001). “Developments in mid-infrared FT-IR spectroscopy of selected carbohydrates,” Carbohydrate Polymers 44(4), 291-303.

Kharazipour, A. (2004). "Holz als Werkstoff,” Jahrbuch 2004/2005, Nachwachsende Rohstoffe, Wirtschaftsfaktor Biomasse, C.A.R.M.E.N. e.V., ed., Straubing.

Kloeser, L., Kües, U., Schöpper, C., Hosseinkhani, H., Schütze, S., Dantz1, S., Malik, I., Vos, H., Bartholme, M.., Müller, C., Polle, A., and Kharazipour, A. (2008). "Panel boards and conventional adhesives," Wood Production, Wood Technology and BioTechnological Impacts, U. Kües, ed., Universitätsverlag, Göttingen.

Kollmann, F., and Fengel, D. (1965). “Änderung der chemischen Zusammensetzung von Holz durch thermische Behandlung,” Holz als Roh- und Werkstoff 12, 461-468.

Körner, S., Niemz, P., Wienhaus, O., and Henke, R. (1992). “Orientierende Untersuchungen zum Nachweis des Klebstoffanteils auf Holzpartikeln mit Hilfe der FTIR-Spektroskopie,” Holz als Roh- und Werkstoff 50, 67-72.

Kubo, S., and Kadla, J.-F. (2005). "Hydrogen bonding in lignin: A Fourier transform infrared model compound study,” Biomacromolecules 6, 2815-2821.

Lohmann, U. (1998). Holzhandbuch, DRW-Verlag, Leinfelden-Echterdingen.

McCann, M. C., Chen, L., Roberts, K., Kemsley, E. K., Sene, C., Carpita, N. C., Stacey, N. J., and Wilson, R. H. (1997). "Infrared microspectroscopy: Sampling heterogeneity in plant cell wall composition and architecture,” Physiol. Plant. 100(3), 729-738.

Medved, S., and Resnik, J. (2004). "Influence of particle size on the surface covered with adhesive at particles from beech wood,” Wood Research (Bratislava) 49(1), 33-40.

Naumann, D., Labischinski, H., and Giesbrecht, P. (1991). "The characterization of microorganisms by Fourier transform infrared spectroscopy (FT/IR),” Modern Techniques for Rapid Microbial Analysis, W. H. Nelson (ed.), VCH, New York.

Naumann, A., Peddireddi, S., Kües, U., and Polle, A. (2007). "Fourier transform microscopy in wood analysis,” Wood Production, Wood Technology and BioTechnological Impacts, Kües, U. (ed.), Universitätsverlag, Göttingen.

Nörr, R. (2004). "Vom Exoten zur Wirtschaftsbaumart: 175 Jahre Douglasienanbau in Deutschland,“ LWF Aktuell 45, 7-9.

Ohlmeyer, M. (2002). “Untersuchung über die Eigenschaftsentwicklung von Holzwerkstoffplatten nach dem Heißpressen,” Dissertation, Universität Hamburg, 
Hamburg, Germany, (http://deposit.ddb.de/cgi-bin/dokserv?idn=965220273 \&dok var=d1\&dok_ext=pdf\&filename=965220273.pdf).

Pakdel, H., Cyr, P.-L., Riedl, B., and Deng, J. (2008). “Quantification of urea formaldehyde resin in wood fibers using X-ray photoelectron spectroscopy and confocal laser scanning microscopy,” Wood Science and Technology 42(2), 133-148.

Pandey, K. K. (1999). “A study of chemical structure of soft and hardwood and wood polymers by FTIR spectroscopy,” Journal of Applied Polymer Science 71(12), 19691975.

Pandey, K. K., and Pitman, A. J. (2003). "FTIR-ATR studies of the changes in wood chemistry following decay by brown-rot and white-rot fungi," Intern. Biodeterior. Biodegr. 52(3), 151-160.

Pandey, K. K., and Pitman, A. J. (2004). “Examination of lignin content in a softwood and a hardwood decayed by a brown-rot fungus with acetyl bromide method and Fourier transform infrared spectroscopy,” J. Polym. Sci. A: Polym. Chem. 42, 23402346.

Parker, F. S. (1983). Application of Infrared, Raman and Resonance Raman Spectroscopy in Biochemistry. Plenum Press, New York.

Pöyry Forest Industry Consulting (2006). "Wood-based panels,” JP Viewpoint-Europe.

Reich, I. (2008). “Das Holz wird knapp und teuer,” Handelsblatt, Verlagsgruppe Handelsblatt, Düsseldorf, (http://www.handelsblatt.com/unternehmen/industrie/dasholz-wird-knapp-und-teuer;1375884).

Rennenberg, H., Seiler, W., Matyssek, R., Gessler, A., and Kreuzwieser, J. (2004). “Die Buche (Fagus sylvatica L.) - Ein Waldbaum ohne Zukunft im südlichen Mitteleuropa?,” Allgemeine Forst- und Jagdzeitung 175, 210-224.

Röhrig, E. (1981). "Neuere Grundlagen für den Anbau von Abies grandis,” Schriften aus der Forstlichen Fakultät der Universität Göttingen und der Niedersächsischen Forstlichen Versuchsanstalt, Sauerländer Verlag, Frankfurt am Main.

Rowell, R.M., and LeVan-Green, S.L. (2005) “Thermal properties,” Handbook of Wood Chemistry and Wood Composites, R.M. Rowell ed., CRC Press, Boca Raton. 121138.

Sasol Wax GmbH. (2008). Produkt-Informations-Blatt HydroWax 730

Sasol Wax GmbH. (2008). Produkt-Informations-Blatt HydroWax 138

Schöpper, C. (2006). “Entwicklung eines naturnahen Bindemittels aus nachwachsenden Rohstoffen auf Proteinbasis zur Herstellung von Mitteldichten Faserplatten,” Dissertation, University of Göttingen, Göttingen.

Sivonen, H., Maunu, S. L., Sundholm, F., Jämsä, S., and Viitaniemi, P. (2002). "Magnetic resonance studies of thermally modified wood," Holzforschung 56, 648654.

Spellmann, H., and Kehr, I. (2008). "The wood supply in the world, Europe, Germany, and Lower Saxony,” In: Wood Production, Wood Technology and Bio-Technological Impacts, Kües, U. (ed.), Universitätsverlag, Göttingen, 43-55.

Usmanov, K. U., Yulchibaev, A. A., Dordzhin, G. S., and Valiev, A. (1972). "IR spectroscopic analysis of graft co-polymers of cellulose and its derivatives with vinyl fluoride,” Fibre Chemistry 3(3), 292-295.

Wagenführ, R. (2000) Anatomie des Holzes, DRW-Verlag, Leinfelden-Echterdingen. 
Williams, R. S. (2005). "Weathering of wood”, Handbook of Wood Chemistry and Wood Composites, R. M. Rowell (ed.), CRC Press, Boca Raton, 139-185

Wolf, M. (2005). "Freihandel und Umwelt,” Außenpolitische Jahrestagung der BöllStiftung, 03.06.2005, Berlin, (http://www.bmu.de/reden/archiv/15/wolf/doc/35592.php).

Youngquist, J. A., Krzysik, A. M., Chow, P., and Menimban, R. (1997). "Properties of composite panels,” Paper and Composites from Agro-Based Resources, Rowell, R. M., Young, R. A., and Rowell, J. K. (eds.), CRC/Lewis Publishers, Boca Raton, 301336.

Article submitted: Sept. 15, 2008; Peer review completed: Oct. 27, 2008; Revised version received and accepted: Nov. 12, 2008; Published: Nov. 12, 2008. 